Ekuitas: Jurnal Pendidikan Ekonomi

Volume 7, Number 1, 2019, pp. 14-22

P-ISSN : 2354-6107 E-ISSN : 2549-2292

Open Access: https://ejournal.undiksha.ac.id/index.php/EKU

\title{
Pengaruh Modal Intelektual Terhadap Pertumbuhan Koperasi di Kota Kupang
}

\author{
Jems Arison Zacharias ${ }^{1}$, Renya Rosari ${ }^{2}$ \\ 1,2, Fakultas Ekonomi Universitas Kristen Artha Wacana, Kupang - Indonesia.
}

\section{A R T I C L E I N F O}

Article history:

Received 6 February 2019

Received in revised form

8 May 2019

Accepted 5 June 2019

Available online 15 June

2019

Kata Kunci:

Modal Intelektual, VAIC,

Pertumbuhan Koperasi,

Kota Kupang.

Keywords:

Intellectual Capital, VAIC,

Growth of Cooperatives,

Kupang City.
A B S T R A K

Tujuan dari penelitian ini adalah untuk menemukan hubungan kausalitas antara Modal Intelektual dengan pertumbuhan koperasi di Kota Kupang. Modal Intelektual dalam penelitian ini di ukur dengan menggunakan Value Added Intellectual Coefficient (VAIC) sedangkan pertumbuhan koperasi diukur dengan menggunakan perubahan logaritma natural dari total aset koperasi. Populasi dalam penelitian ini adalah seluruh koperasi yang terdaftar pada Dinas Koperasi dan UKM Kota Kupang. Pemilihan sampel menggunakan purposive sampling, yaitu koperasi-koperasi yang telah mengeluarkan laporan keuangan koperasi dari tahun2011-2017. Model uji yang diterapkan meliputi statistik deskriptif, uji asumsi klasik, analisis regresi sederhana dan berganda. Hasil penelitian menunjukkan bahwa Modal Intelektual (yang diproksikan dengan VAIC) berpengaruh terhadap pertumbuhan koperasi di Kota Kupang. Namun di antara 3 komponen pembentuk VAIC, yaitu CEE (Capital Employed Efficiency), HCE (Human Capital Efficiency), dan SCE (Structural Capital Efficiency), hanya CEE yang berpengaruh signifikan terhadap pertumbuhan koperasi di Kota Kupang. Ini dapat diartikan bahwa secara umum koperasi di Kota Kupang lebih menitikberatkan pertumbuhan usahanya melalui efisiensi penggunaan modal fisik dibanding peningkatan kualitas Sumber Daya Manusia.

\section{A B S T R A C T}

The purpose of this study was to find a causal relationship between Intellectual Capital and the growth of cooperatives in Kupang City. Intellectual capital in this study was measured using Value Added Intellectual Coefficient (VAIC) while the growth of cooperatives was measured using changes in the natural logarithm of the cooperative's total assets. The population in this research were all cooperatives registered with the Kupang Cooperative and SME Office. The sample selection uses purposive sampling, namely cooperatives that have issued cooperative financial statements from 2011-2017. The test model applied includes descriptive statistics, classic assumption tests, simple and multiple regression analysis. The results showed that Intellectual Capital (which is proxied by VAIC) had an effect on the growth of cooperatives in Kupang City. But among the 3 components that make up VAIC, namely CEE (Capital Employed Efficiency), HCE (Human Capital Efficiency), and SCE (Structural Capital Efficiency), only CEE has a significant effect on the growth of cooperatives in Kupang City. This can be interpreted that in general cooperatives in Kota Kupang focus more on the growth of their business through efficient use of physical capital compared to improving the quality of their human resources.

Copyright @ Ekuitas: Jurnal Pendidikan Ekonomi. All rights reserved.

\footnotetext{
* Corresponding author.

E-mail : jemszacharias@gmail.com (Jems Arison Zacharias)
} 
Ekuitas: Jurnal Pendidikan Ekonomi, Vol. 7, No. 1, 2019, 14-23.

\section{Pendahuluan}

Ketika perekonomian global bergeser dari ekonomi berbasis industri kepada ekonomi berbasis pengetahuan, nilai sebuah perusahaan tidak hanya ditentukan oleh aset fisiknya. Para pelaku bisnis mulai menyadari bahwa kemampuan bersaing terletak pada inovasi, sistem informasi, serta pengelolaan sumber daya pengetahuan organisasi. Penggunaan pengetahuan untuk meningkatkan produktivitas merupakan fenomena yang muncul pada era perkembangan teknologi informasi (Iazzolino dan Laise 2013).

Modal intelektual merupakan sekelompok aset pengetahuan yang memiliki kontribusi untuk meningkatkan keunggulan bersaing perusahaan dengan cara memberikan nilai tambah bagi para stakeholder (Starovic dkk. 2003). Nilai tambah ini dapat timbul dari kemampuan organisasi dalam menciptakan, mentransfer, dan mengimplementasikan pengetahuan yang dimilikinya (Rupidara 2005). Menurut Solikhah dkk. (2010), perusahaan yang mampu mengelola sumber daya intelektualnya diyakini mampu menciptakan keunggulan kompetitif dengan cara melakukan inovasi, penelitian dan pengembangan.

Dalam tujuan untuk mencapai keunggulan kompetitif, keberhasilan pertumbuhan dan keberlangsungan perusahaan akan bergantung pada pengembangan sumber-sumber daya baru (Wernerfelt 1984). Sumber daya baru ini dapat dihasikan oleh perusahaan dengan menggunakan modal intelektualnya secara efektif dan efisien. Penggunaan modal intelektualnya ini merupakan fondasi dari perekonomian modern dan diharapkan akan mendorong kemampuan perusahaan untuk lebih berkembang di masa depan (Solikhah dkk. 2010).

Perusahaan yang berinvestasi pada modal intelektual memiliki pertumbuhan yang lebih tinggi dibanding dengan perusahaan yang berinvestasi hanya pada aset-aset fisik seperti mesin dan peralatan (OECD 2013). Ini disebabkan investasi pada modal intelektual dapat menghasilkan knowledge spillover pada masyarakat dan lingkungan bisnis di luar perusahaan yang dapat mendorong percepatan perkembangan ilmu pengetahuan dan teknologi. Selain itu, ketika sebuah pengetahuan telah diciptakan, maka pengetahuan tersebut dapat digunakan kembali tanpa menghasilkan biaya tambahan. Kedua hal ini dapat meningkatkan produktivitas pekerjaan dan pertumbuhan perusahaan (OECD 2013).

Salah satu model yang digunakan untuk menghitung modal intelektual adalah model VAIC (Value Added Intellectual Capital). VAIC didesain untuk menyediakan informasi mengenai efisiensi penciptaan nilai dari aset berwujud dan aset tidak berwujud dalam suatu perusahaan (Pulic 1998). Terdapat tiga komponen utama yang membentuk model VAIC, yaitu capital employed, human capital dan structural capital.

Capital Employed (CE) merupakan modal yang kuasai oleh perusahaan berupa dana keuangan dan aset fisik yang digunakan untuk membantu penciptaan nilai tambah perusahaan (Wiradinata dan Siregar 2011). Human Capital (HC) menunjukkan kemampuan perusahaan dalam mengelola sumber daya manusia. HC menganggap bahwa pengetahuan, keahlian dan kompetensi yang dimiliki oleh pekerja merupakan aset yang bernilai bagi perusahaan. Sedangkan Structural Capital (SC) merupakan modal yang dimiliki oleh perusahaan berupa pengetahuan yang akan tetap berada dalam perusahaan seperti prosedur, database, budaya, rutinitas, dan sistem (Astuti dan Sabeni 2005).

Koperasi memiliki karakteristik utama yang membedakannya dengan bentuk usaha lain. Karakteristik utama tersebut terletak pada identitas ganda anggota koperasi, yaitu anggota koperasi merupakan pemilik koperasi sekaligus pengguna jasa koperasi (Arifin R. 2010). Ini berarti bahwa pertumbuhan dari koperasi merupakan perhatian utama dari setiap anggota koperasi karena setiap anggota koperasi juga merupakan dari pemilik koperasi tersebut. Ketika nilai koperasi mengalami peningkatan, maka kesejahteraan para anggotanya juga akan semakin meningkat. Keberhasilan dari manajemen koperasi untuk dapat meningkatkan kesejahteraan anggotanya dapat dinilai dari key performance indicatornya.

Key performance indicator pada tabel 1 merupakan usaha koperasi untuk membangun manajemen koperasi yang profesional sesuai dengan tuntutan perkembangan zaman namun dengan tidak meninggalkan tujuan dan nilai-nilai koperasi, yaitu memberikan manfaat sebesar-besarnya bagi setiap anggota koperasi. Pada Key performance indicator dapat dilihat bahwa perkembangan sebuah koperasi tidak hanya dinilai dari aset fisiknya (Capital Employed) seperti modal, peralatan dan bahan baku, namun juga pada aset pengetahuan yang melekat pada sumber daya manusia koperasi (Human Capital) serta metode/aturan yang dikembangkan oleh koperasi (Structural Capital). Tujuannya adalah mengembangkan semangat kewirausahaan dan inovasi koperasi, menciptakan nilai tambah yang unggul dibandingkan pesaingnya, serta menghasilkan pertumbuhan koperasi yang sehat ditengah pertumbuhan bisnis yang didasarkan pada perkembangan teknologi dan informasi yang semakin pesat. 
Tabel 1

Key Performance Indicator Manajemen Koperasi

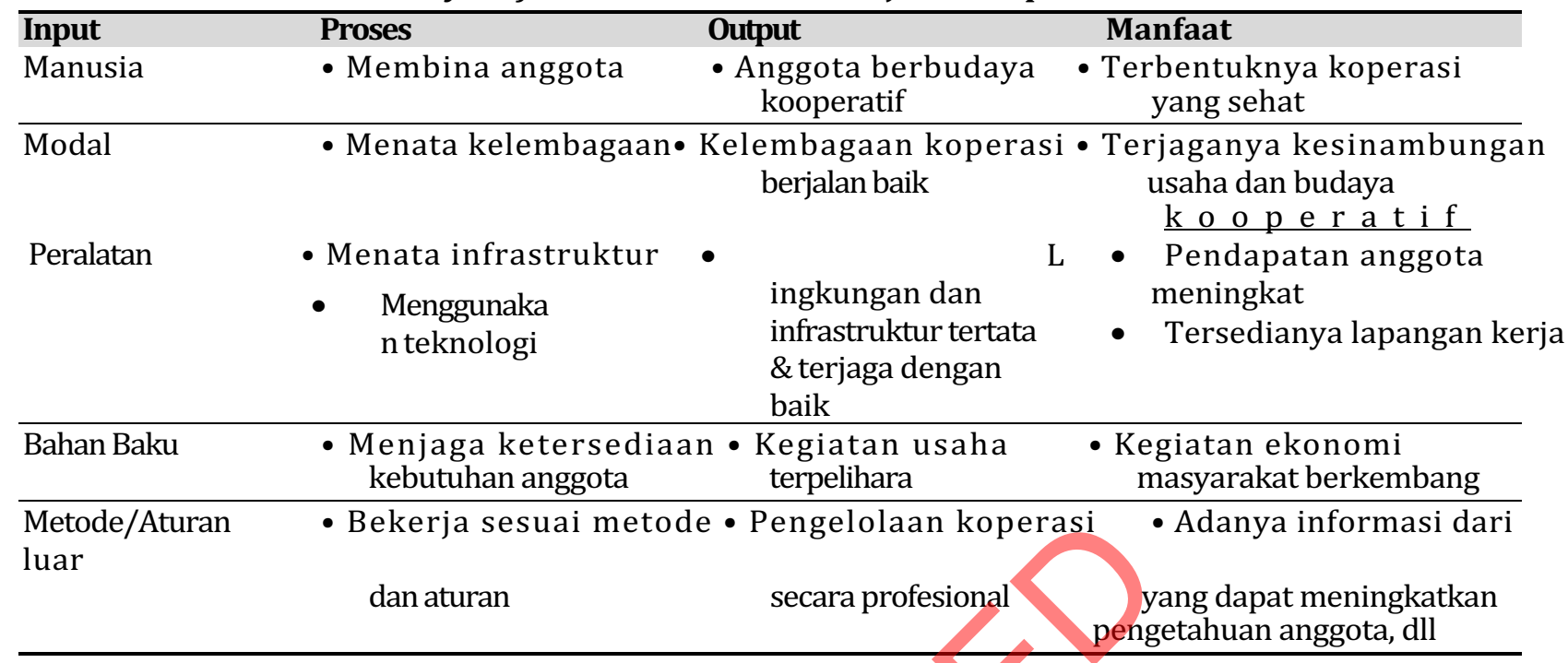

Sumber: Kementrian Koperasi dan UKM RI (2002)

Berdasarkan uraian latar belakang penelitian di atas, peneliti termotifasi untuk melakukan penelitian mengenai pengaruh modal intelektual terhadap pertumbuhan koperasi di Kota Kupang.

\section{Kajian Pustaka}

Pulic (2000) mengklaim bahwa dalam ekonomi modern, investasi dalam pengetahuan untuk menciptakan nilai telah menjadi strategi kompetitif utama perusahaan. Dengan menciptakan nilai maka perusahaan tersebut dapat bertahan dan berkembang dalam lingkungan persaingan usaha yang ketat. Pengetahuan dan penciptaan nilai adalah dua hal yang saling berhubungan dalam ekonomi modern.

Menurut Pulic (2008), pengeluaran yang dilakukan untuk meningkatkan kualitas sumber daya manusia dari sebuah organisasi merupakan salah satu contoh investasi dalam pengetahuan. Jika hal tersebut pada akhirnya dapat meningkatkan produktivitas dari sumber daya manusia dalam organisasi tersebut, maka nilai organisasinya juga meningkat. Pengukuran produktivitas dari para pekerja dalam sebuah organisasi berbasis pengetahuan merupakan salah satu masalah yang sering timbul.

Agar dapat memecahkan masalah ini, Pulic (2008) menunjukkan bahwa adalah suatu hal yang sangat penting untuk mengidentifikasikan sebuah metodologi yang dapat untuk mengukur produktivitas dari sebuah pekerjaan intelektual. VAIC dikembangkan oleh Pulic (1998) sebagai instrumen dalam mengukur kinerja dari sebuah organisasi berbasis pengetahuan. Model ini menyajikan informasi tentang penciptaan nilai dari aset berwujud maupun aset tidak berwujud perusahaan (Salim dan Karyawati 2013).

Untuk dapat mengukur produktivitas dan penciptaan nilai yang dilakukan oleh para pekerja berbasis pengetahuan di dalam sebuah organisasi, Pulic (2008) memulainya dengan mengunakan Value Added Income Statement pada tabel 2 sebagai berikut:

Tabel 2

"Value-Added" Income Statement

\begin{tabular}{ll} 
Pendapatan/penjualan & OUT \\
- Beban (Selain beban gaji dan upah) & IN \\
= Nilai Tambah (Value added) & VA \\
- Beban Gaji dan Upah & HC \\
= Modal Struktural & SC \\
- Amortisasi dan Depresiasi & A + D \\
= Laba Operasional & P \\
\hline
\end{tabular}

Sumber: Iazzolino dan Laise (2013) 


\section{Metode}

Penelitian ini menggunakan dua jenis variabel yaitu variabel bebas yaitu modal intelektual dan variabel terikat yaitu pertumbuhan koperasi. Variabel bebas berupa modal intelektual di ukur dengan menggunakan VAIC (Value Added Intellectual Coefficient) yang terdiri atas CEE (Capital Employed Efficiency), HCE (Human Capital Efficiency) dan SCE (Structural Capital Efficiency). Variabel terikat berupa pertumbuhan koperasi yang di ukur dengan menggunakan perubahan logaritma natural dari total aset koperasi.

Formulasi Perhitungan VAIC adalah sebagai berikut:

VA (Value Added)

$\mathrm{VA}=$ Output - Input .

Keterangan:

- Output = Pendapatan/Penjualan

- Input = Beban (kecuali gaji, upah, serta beban pendidikan dan pelatihan SDM)

\section{CEE (Capital Employed Efficiency)}

$\mathrm{CEE}=\mathrm{VA} / \mathrm{CE}$

Keterangan:

- $\mathrm{VA}=$ Value Added

- $\mathrm{CE}=$ Capital Employed (Kekayaan bersih/net asset - aset tidak berwujud)

\section{HCE (Human Capital Efficiency)}

$\mathrm{HCE}=\mathrm{VA} / \mathrm{HC}$

Keterangan:

- $\mathrm{VA}=$ Value Added

- $\quad \mathrm{HC}=$ Human Capital (gaji, upah, serta beban pendidikan dan pelatihan SDM)

\section{SCE (Structural Capital Efficiency)}

SCE $=$ SC/VA

Keterangan:

- $\mathrm{VA}=$ Value Added

- $\mathrm{SC}=$ Structural Capital (VA-HC)

Sedangkan pertumbuhan koperasi dihitung dengan menggunakan perubahan logaritma natural dari total asset koperasi sebagai berikut:

\section{Cooperative Growth}

$\Delta \ln \mathrm{Si}, \mathrm{t}=\ln \mathrm{Si}, \mathrm{t}-\ln \mathrm{Si}, \mathrm{t}-1$ (Fulton E.,M., dkk 1995)

Keterangan:

- $\quad$ In Si,t = Logaritma natural dari ukuran aset (asset size) koperasi i pada periode waktu t. Ukuran aset pada penelitian ini menggunakan total asset koperasi

- $\quad$ ln Si,t-1 = Logaritma natural dari ukuran aset (asset size) koperasi i pada periode waktu t-1 (periode waktu sebelumnya)

Model yang digunakan dalam penelitian ini adalah regresi linear sederhana dan berganda.

$$
\begin{aligned}
& \ln S=.0+\mathrm{VAIC}+ \\
& \ln S=0+1 \mathrm{CEE}+.2 \mathrm{HCE}+{ }_{3} \mathrm{SCE}+
\end{aligned}
$$

Keterangan:

$\ln \mathrm{S}$

0,0

$1,1,2,3$

CEE

HCE

SCE

VAIC
$=$ Perubahan logaritma natural dari total asset koperasi

$=$ Intercept

= Koefesien Regresi

= Capital Employed Efficiency

= Human Capital Efficiency

= Structural Capital Efficiency

$=\mathrm{CEE}+\mathrm{HCE}+\mathrm{SCE}$

$=$ Error 
Jenis data yang dikumpulkan dalam penelitian ini adalah data kuantitatif. Sumber data menggunakan data sekunder berupa laporan keuangan koperasi. Laporan keuangan ini didapatkan dari koperasi yang telah ditetapkan sebagai sampel tersebut. Populasi di dalam penelitian adalah seluruh koperasi di Kota Kupang yang terdaftar di Dinas Koperasi dan UKM Kota Kupang. Proses pemilihan sampel menggunakan metode purposive sampling atau teknik penentuan sampel dengan pertimbangan tertentu (Sugiyono, 2014). Kriteria yang digunakan dalam pemilihan sampel peneltian ini adalah koperasi yang memiliki laporan keuangan selama periode pengamatan, yaitu dari tahun 2011 sampai 2017.

Tabel 3

Data Sampel Koperasi-Koperasi di Kota Kupang

\begin{tabular}{|c|c|c|c|}
\hline & Nama Koperasi & No. Ijin & Alamat \\
\hline 1. & $\begin{array}{l}\text { KOPKAR BRI Gemah } \\
\text { Ripah }\end{array}$ & 25/BH/KWK.24/IV/IV/1 996. 12 April 1996 & Jln. Ir. Soekarno No.18 \\
\hline 2. & KPN Bougenville & 574/BH/XIV. 31 Agustus 1989 & $\begin{array}{l}\text { Jln. Alfons Nisnoni } \\
\text { No19 }\end{array}$ \\
\hline 3. & $\begin{array}{l}\text { KSU BMT } \\
\text { Nurussa'adah }\end{array}$ & 162/BH/KDK/24.1/XI/2000 & Jln. Ir. Soekarno No.24 \\
\hline 4. & KOPDIT Swastisari & 1 0/PAD/KWK/24/I V/1 997. 10 April 19 & $\begin{array}{l}\text { Jln Perintis } \\
\text { Kemerdekaan, Kel. } \\
\text { Kelapa Lima }\end{array}$ \\
\hline 5. & KSU Dewi Gangga & $\begin{array}{l}\text { 06/BH/XXIX.6/2007. } 29 \text { Oktober } 2007 \\
\text { 256/PAD/KWK.24/X/2001 }\end{array}$ & $\begin{array}{l}\text { BTN Samping Pura, Kel. } \\
\text { Kolhua } \\
\text { Jln Adi sucipto No.25 }\end{array}$ \\
\hline
\end{tabular}

Sumber: Dinas Koperasi dan UKM Kota Kupang, 2017

Data yang telah dikumpulkan pertama kali akan digambarkan melalui deskriptif statistik. Selanjutnya, pengujian hipotesis akan dianalisis dengan menggunakan regresi linear berganda. Namun sebelum hasil kesimpulan diambil berdasarkan hasil uji regresi, terlebih dahulu akan dilakukan pengujian asumsi klasik. Ini dikarenakan model regresi yang baik merupakan model regresi yang bebas dari gejala asumsi klasik yaitu: tidak ada multikolenieritas, tidak ada autokorelasi, tidak terjadi gejala heterokedastisitas dan adanya normalitas.

\section{Hasil dan pembahasan}

\begin{tabular}{|c|c|c|c|c|c|}
\hline & $\mathrm{N}$ & aimum & Maksimum & Nilai Rata-Rata & Deviasi Standar \\
\hline DeltaLnSize & 42 & $-0,239$ & 0,418 & 0,14348 & 0,138784 \\
\hline CEE & 42 & 0,089 & 0,314 & 0,18436 & 0,056326 \\
\hline HCE & 42 & 0,050 & 1,337 & 0,34838 & 0,304333 \\
\hline SCE & 42 & 0,190 & 0,960 & 0,59738 & 0,288729 \\
\hline VAIC & 42 & 0,532 & 1,788 & 1,13014 & 0,342580 \\
\hline Valid N (listwise) & 42 & & & & \\
\hline
\end{tabular}

Sumber: Data sekunder diolah, 2018

Jumlah data yang digunakan sebagai sampel sebanyak 42 data, dengan nilai maksimum (minimum) untuk variable terikat $\Delta \ln S$ adalah -0,23 9 (minimum), 0,418 (maksimum), nilai rata- rata 0,143 dengan deviasi standar sebesar 0,13 8. Nilai maksimum, minimum, rata-rata dan deviasi standar untuk variablevariabel lainnya dapat dilihat pada tabel 4 di atas. 0,618. 
Tabel 5

Hasil Uji Normalitas untuk setiap Model Regresi

\begin{tabular}{|c|c|c|}
\hline Model Regresi & Sgg & Kesimpulan \\
\hline$A \ln S=a 0+a 1 V A I C+c$ & 0,330 & $\mathrm{Norma} \mathrm{l}$ \\
\hline$\underline{A l n} S=30+31 \mathrm{CEE}+32 \mathrm{HCE}+3_{3} \mathrm{SCE}+\mathrm{C}$ & 0,618 & Normal \\
\hline
\end{tabular}

Sumber: Data sekunder diolah, 2018

Hasil uji normalitas dapat dilihat pada Tabel 5. Pada uji Kolmogorov-Smirnov, jika signifikansi di bawah 0,05 berarti data tersebut tidak normal. Sedangkan jika signifikansi di atas 0,05 berarti data tersebut normal. Hasil uji normalitas menunjukkan tingkat signifikan pada 0,618 dan 0,330. Hal ini menunjukkan bahwa data terdistribusi normal.

Tabel 6

Hasil Uji Multikolinieritas

\begin{tabular}{ccc}
\hline Variabel Bebas & Tolarance & VIF \\
\hline CEE & 0,453 & 2.210 \\
HCE & 0,349 & 2.868 \\
SCE & 0,597 & 1.674 \\
VAIC & 1.000 & 1.000 \\
\hline Sumber: Data sekunder diolah, 2018 & &
\end{tabular}

Uji multikolinieritas digunakan untuk mengetahui adanya korelasi antara variabel bebas. Salah satu cara mendeteksi multikolinieritas adalah dengan melihat nilai VIF dan nilai tolerance. Jika nilai VIF kurang dari 10 dan nilai tolerance di atas 0,10 dapat disimpulkan bahwa tidak terdapat gejala multikolinieritas. Berdasarkan tabel hasil pengujian pada Tabel 6, dapat diketahui bahwa bahwa tidak terjadi multikolinieritas antara variabel bebas.

Tabel 7

Hasil Uji Autokorelasi untuk setiap Model Regresi

\begin{tabular}{lcc}
\hline \multicolumn{1}{c}{ Model Regresi } & d & 4-d \\
\hline $\mathbf{A} \ln \mathbf{S}=\mathbf{a 0}+\mathbf{a 1}$ VAIC + c & 2,175 & 1,825 \\
\hline $\mathbf{A} \ln \mathbf{S}=\mathbf{3 0}+\mathbf{3 1}$ CEE + 32 HCE + 33 SCE + c & 2,119 & 1,881
\end{tabular}

Sumber: Data sekunder diolah, 2018

Uji autokorelasi bertujuan untuk mendeteksi antara kesalahan penggangu pada periode $t$ dengan kesalahan penggangu pada periode sebelumnya. Jenis pengujian yang dilakukan untuk mengetahui autokorelasi adalah uji Durbin-Watson. Hasil pengujian pada tabel 7 di persamaan pertama menunjukkan bahwa nilai Durbin-Watson atau d =2,175 dan nilai $(4-d)=1,825$. Nilai d dan (4-d) ini lebih besar dari nilai dU = 1,600 sehingga dapat diartikan bahwa tidak dapat autokorelasi positif dan negatif pada model regresi pertama. Sedangkan pada persamaan kedua nilai $d=2,119$ dan nilai $(4-d)=1,881$ lebih besar dari nilai dU = 1,720 yang dapat berarti bahwa tidak terdapat autokorelasi positif pada model regresi kedua.

Tabel 8

Hasil Uji Heteroskedastisitas

\begin{tabular}{|c|c|c|}
\hline Variabel Bebas & 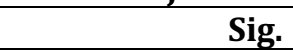 & Kesimpulan \\
\hline CEE & 0,435 & Non heteroskedastisitas \\
\hline HCE & 0,384 & Non heteroskedastisitas \\
\hline SCE & 0,513 & Non heteroskedastisitas \\
\hline VAIC & 0,069 & Non heteroskedastisitas \\
\hline
\end{tabular}

Sumber: Data sekunder diolah, 2018 
Uji heterokedastisitas digunakan untuk melihat apakah terdapat ketidaksamaan varians residual dari pengamatan satu ke pengamatan yang lain. Uji Glejser dilakukan dengan cara meregreskan nilai absolut residual terhadap variabel bebas di dalam persamaan regresi. Jika variabel bebas signifikan mempengaruhi variabel terikat berarti terdapat gejala heterokedastisitas. Dari hasil pengujian pada tabel 8 di atas, dapat dilihat bahwa nilai signifikansi masing-masing variabel bebas dalam persamaan regresi di atas lebih besar dari 0,05 sehingga dapat diambil kesimpulan bahwa seluruh variabel bebas tidak berpengaruh pada nila absolut residual atau tidak terjadi heterokedastisitas.

Tabel 9

Hasil Analisis Model Regresi I

\begin{tabular}{ccc}
\hline In S $=.0+.1$ VAIC.+ & Koefisien & Sig. \\
\hline Intercept & 1,036 & 0,023 \\
VAIC & 0,753 & 0,049 \\
\hline R Square & 0,094 & \\
\hline
\end{tabular}

Sumber: Data sekunder diolah, 2018

Dari hasil uji t model regresi pertama di tabel 9, dapat dilihat bahwa variabel bebas VAIC (Modal Intelektual) berpengaruh terhadap variabel terikat Aln S (Pertumbuhan Koperasi di Kota Kupang) karena nilai signifikannya 0,049 lebih kecil dari nilai a 0,05. Sedangkan R Square sebesar 0,094 pada tabel 9 memiliki arti bahwa variasi dari variabel terikat Aln S (Pertumbuhan Koperasi di Kota Kupang) yang dapat dijelaskan oleh variasi dari variabel bebas VAIC (Modal Intelektual) adalah sebesar 9,4\%.

\section{Tabel 10}

Hasil Analisis Model Regresi II

${ }_{1} \ln \mathrm{S}={ }_{30}+{ }_{31} \mathrm{CEE}+{ }_{3} 2 \mathrm{HCE}+{ }_{33} \mathrm{SCE}+。$

\begin{tabular}{lll}
\hline & Koefesien & Sig. \\
\hline Intercept & 0,238 & 0,007 \\
\hline CEE & 1,122 & 0,049 \\
\hline HCE & 0,104 & 0,377 \\
\hline SCE & 0,127 & 0,184 \\
\hline R Square & 0,135 & \\
\hline
\end{tabular}

Sumber: Data sekunder diolah, 2018

Pada model regresi kedua, pengaruh parsial variabel bebas CEE (Capital Employed Efficiency), HCE (Human Capital Efficiency), dan SCE (Structural Capital Efficiency) terhadap variabel terikat Pertumbuhan Koperasi di Kota Kupang dapat dilihat dari hasil uji t pada tabel 10. Hasil perhitungan SPSS pada tabel 10 menunjukkan bahwa variabel bebas CEE memiliki pengaruh terhadap variabel terikat Aln S (Pertumbuhan Koperasi di Kota Kupang) karena nilai signifikannya sebesar 0,049 lebih kecil dari nilai a 0,05. Sedangkan kedua variabel bebas lainnya, yakni HCE dan SCE tidak memiliki pengaruh terhadap variabel terikat Aln S (Pertumbuhan Koperasi di Kota Kupang) karena nilai signifikannya yang lebih besar dari a 0,05. Nilai $R$ Square sebesar 0,135 pada tabel 10 memiliki arti bahwa variasi dari variabel terikat Aln S (Pertumbuhan Koperasi di Kota Kupang) yang dapat dijelaskan oleh variasi dari variabel bebasnya, yaitu CEE, HCE, dan SCE adalah sebesar 13,5\%.

Berdasarkan hasil perhitungan dari model-model regresi sebelumnya maka dapat dibuktikan bahwa H1 diterima. Dengan kata lain, Modal Intelektual berpengaruh terhadap pertumbuhan koperasi di Kota Kupang. Ini dapat dilihat dari nilai signifikan VAIC sebesar 0,049 yang lebih kecil dari nilai a 0,05. Hasil penelitian ini sesuai dengan Resource-Based Theory yang kemukakan oleh Wernerfelt (1984) bahwa entitas usaha akan memiliki kinerja yang baik dalam menghadapi persaingan usaha ketika entitas usaha tersebut dapat memanfaatkan aset-aset strategisnya, baik berwujud maupun tidak berwujud seperti aset pengetahuan. Hasil penelitian ini juga mendukung penelitian yang dilakukan oleh Solikhah (2010) mengenai peran modal intelektual dalam mendukung pertumbuhan entitas usaha. Solikhah (2010) menemukan bahwa modal intelektual berpengaruh positif terhadap kinerja keuangan dan pertumbuhan perusahaan-perusahaan manufaktur yang terdaftar di BEI (Bursa Efek Indonesia). 
Ekuitas: Jurnal Pendidikan Ekonomi, Vol. 7, No. 1, 2019, 14-23.

Dari ketiga variabel yang membentuk VAIC, yaitu CEE (Capital Employed Efficiency), HCE (Human Capital Efficiency), dan SCE (Structural Capital Efficiency), hanya CEE (Capital Employed Efficiency) yang berpengaruh terhadap pertumbuhan koperasi di Kota Kupang. Sedangkan pada kedua variabel lainnya, yaitu HCE dan SCE, tidak berpengaruh terhadap pertumbuhan koperasi di Kota Kupang. Penelitian ini memperkuat peran CEE dalam model VAIC seperti penelitian yang dilakukan oleh Aritonang dan Sugiono (2016) mengenai pengaruh modal intelektual terhadap kinerja keuangan perusahaan-perusahaan yang terdaftar di BEI. Aritonang dan Sugiono (2016) menemukan bahwa CEE merupakan indikator yang paling signifikan ketika menggunakan model VAIC dalam menentukan kinerja keuangan perusahaan di masa depan.

CEE merupakan nilai tambah atau value added yang dihitung tanpa memperhitungkan faktor SDM yang diproksikan melalui beban gaji dan kemudian dibagi dengan total aset bersih koperasi. CEE menunjukkan seberapa besar kemampuan aset bersih koperasi dalam menghasilkan nilai tambah secara umum tanpa dipengaruhi oleh faktor SDM koperasi. Nilai CEE yang signifikan di antara variabel-variabel lainnya seperti HCE dan SCE dalam model VAIC menandakan bahwa untuk koperasi di Kota Kupang lebih menitikberatkan pertumbuhan usahanya melalui efisiensi penggunaan modal fisiknya daripada peningkatan kualitas SDMnya.

Hasil pengujian juga menunjukkan bahwa HCE tidak berpengaruh terhadap pertumbuhan koperasi di Kota Kupang. HCE merupakan kemampuan dari SDM koperasi yang diproksikan dengan biaya gaji dalam menghasilkan nilai tambah atau value added. Gaji serta beban pelatihan dan pengembangan SDM yang diadakan oleh koperasi di Kota Kupang ternyata belum mampu berkontribusi untuk meningkatkan nilai tambah koperasi. Hal ini dapat menunjukkan kualitas SDM koperasi di Kota Kupang yang masih rendah dan belum dapat bersaing dalam memanfaatkan aset pengetahuan untuk meningkatkan produktivitas kerja serta menciptakan nilai tambah dalam era revolusi industri 4.0 sekarang ini.

Selain HCE, hasil penelitian juga menunjukkan bahwa Structural Capital Efficiency atau SCE tidak berpengaruh terhadap pertumbuhan koperasi di Kota Kupang. Inti dari SCE berfokus pada seperangkat pengetahuan yang melekat dalam pro sedur rutinitas pada sebuah entitas usaha (Bontis, 2002a: 632). Seperangkat pengetahuan ini akan tetap tinggal di dalam organisasi meskipun para manajer dan karyawan telah meninggalkan tempat kerjanya (Grasenick dan Low, 2004; Mouritsen dan Koleva, 2004).

Hasil SEC yang tidak signifikan ini menunjukkan bahwa koperasi di Kota Kupang belum menggunakan nilai tambahnya untuk menciptakan sebuah Structural Capital seperti prosedur, pengelolaan sistem, dan database yang optimal untuk dapat mendukung pertumbuhannya. Ini dikarenakan desain Structural Capital yang baik sebenarnya dapat menjadi lingkungan bagi karyawan koperasi untuk dapat menghasilkan kinerja intelektual yang tinggi. Namun tanpa adanya dukungan prosedur, sistem dan database yang baik, maka produktivitas kinerja intelektual karyawan juga tidak akan maksimal.

\section{Simpulan dan saran}

Berdasarkan hasil analisis model regresi, maka dapat diambil kesimpulan bahwa Modal Intelektual (yang diproksikan oleh VAIC atau (Value Added Intellectual Coefficient) berpengaruh terhadap pertumbuhan koperasi-koperasi di Kota Kupang. Akan tetapi, di antara 3 komponen pembentuk VAIC, yaitu CEE (Capital Employed Efficiency), HCE (Human Capital Efficiency), dan SCE (Structural Capital Efficiency), hanya CEE yang berpengaruh signifikan terhadap pertumbuhan koperasi di Kota Kupang. Untuk itu peneliti memberikan saran bagi pengembangan koperasi di Kota Kupang sebagai berikut:

1. Koperasi perlu membangun Sistem Informasi Manajemen yang sederhana dan aplikatif sebagai Structural Capitalnya untuk mendukung dalam melakukan perencanaan, pengorganisasian sumber daya serta evaluasi kinerja pengurus, manajemen, dan anggota koperasi. Sistem Informasi Manajemen yang dikembangkan dengan baik oleh koperasi dapat dipakai untuk melatih sumber daya manusianya dalam memproses dan menganalisis informasi strategis sebagai aset pengetahuan yang penting pada era revolusi industri 4.0 ini.

2. Perlu adanya sosialisasi, pelatihan dan pendidikan yang berkelanjutan bagi para anggota koperasi, khususnya dalam hal kewirausahaan koperasi sehingga anggota-anggota koperasi memiliki pengetahuan dan keahlian kewirausahaan yang bisa diaplikasikan secara berkelompok melalui wadah koperasi. Tujuan akhirnya adalah nilai koperasi meningkat, koperasi mengalami pertumbuhan yang stabil dan positif, serta anggota koperasi maupun masyarakat sekitar bisa mendapatkan manfaat ekonomi, sosial, maupun pendidikan dari kegiatan berkoperasi. 


\section{Daftar Rujukan}

Arifin, R. 2010. Manajemen Koperasi Berbasis Nilai-Nilai Intrinsik. IKOPIN, Bandung.

Aritonang Dan Sugiono. 2016. Pengaruh Intellectual Capital Terhadap Kinerja Keuangan (Studi Pada Perusahaan Non Keuangan Yang Terdaftar Di Bursa Efek Indonesia periode Tahun 2012 - 2014). Jurnal Bisnis Strategi. Vol. 25 No. 1.

Astuti dan Sabeni. 2005. Hubungan Intellectual Capital dan Business Performance dengan Diamond Specification: Sebuah Perspektif Akuntansi. SNA VIII Solo.

Belkaoui. 2003. Intellectual capital and firm performance of US multinational firms: a study of the resource-based and stakeholder views. Journal of Intellectual Capital. Vol. 4, No. 2, pp. 215-226.

Bontis, N. 2002, There is a Price on Your Head: Managing Intellectual Capital Strategically. Business Quarterly. Summer, pp. 40-47.

Dinas Koperasi dan UKM Kota Kupang. 2017. Data Keragaan Koperasi dan UKM Kota Kupang. Kupang.

Fulton, E., M., Fulton, R., J., Clark, Parliament. 1995. Cooperative Growth: Is it constrained? Agribusiness, John Wiley \& Sons, Inc. Vol.11, No.3, pp.245-261.

Grasenick, K., dan Low, J. 2004. Shaken, Not Stirred: Defining and Connecting Indicators for the Measurement and Valuation of Intangibles. Journal of Intellectual Capital. 5(2), 268-281.

Hanel, A. 1989. Pokok-Pokok Mengenai Organisasi Koperasi dan Kebijaksanaan Pengembangan di negara Berkembang. UNPAD, Bandung.

Iazzolino, Laise, dan Migliano. 2014. Measuring Value Creation. Measuring Business Excellence. Vol.18, No.1, pp.8-21.

Iazzolino dan Laise. 2013. Value added intellectual coefficient (VAIC): a methodological and critical review. Journal of Intellectual Capital, Vol.14, No.4, pp.547-563.

Kementrian Koperasi dan UKM RI. 2002. Serial Buku Pintar Manajemen Keuangan Koperasi. Jakarta.

Mouritsen, J., dan Koleva, G. (2004). The Actorhood of Organizational Capital. International Journal of Learning and Intellectual Capital. 1(2), 177-189.

OECD report. 2013. New Sources of Growth: Knowledge-based Capital. Paris. Available at: http:www.oecd.org. Diakses tanggal 12 Maret 2016.

Pulic, A. 2008. The Principles of Intellectual Capital Efficiency. A Brief Description, Croatian Intellectual Capital Center, Zagreb.

. 2000. VAIC ${ }^{\mathrm{TM}}$ - an accounting tool for IC management. International Journal of Technology Management, Vol.20, Nos 5-8, pp.702-714.

. 1998. Measuring the performance of intellectual potential in the knowledge economy.

Paper presented at 2nd World Congress on the Management of Intellectual Capital, Hamilton, Ontario, Canada, January 21-23, pp. 21-23.

Rupidara, Neil. 2008. "Modal Intelektual dan Strategi Pengembangan Organisasi dan Sumber Daya Manusia". Paper disajikan pada Diskusi Modal Intelektual UKSW. Salatiga, 21 February 2008.

Sugiyono. 2014. Metode Penelitian Bisnis. CV.Alfabeta, Bandung.

Salim dan Karyawati. 2013. Pengaruh Modal Intelektual Terhadap Kinerja Keuangan. Journal of Business and Entrepreneurship, Vo.1, No.2, pp.54-66.

Solikhah, Badingatus, dkk. 2010. Implikasi Intellectual Capital Terhadap Financial Performance, Growth dan Market Value: Studi Empiris Dengan Pendekatan Simplistic Specification. SNA XIII Purwokerto.

Starovic, et.al. 2003. Handbook for Chartered Institute of Management Accountants. Published by Chartered Institute of Management Accountants.

Ulum, Ihyaul, dkk. 2008. Intellectual Capital dan Kinerja Keuangan Perusahaan; Suatu Analisis dengan Pendekatan Partial Least Squares. SNA XI Pontianak.

Wiradinata dan Siregar. 2011. Pengaruh Modal Intelektual Terhadap Kinerja Keuangan Pada Perusahaan Sektor Keuangan Yang Terdaftar Di Bursa Efek Indonesia. Jurnal Akuntansi \& Manajemen, Vol.22, No.2, pp.107-124

Wernerfelt, B. 1984. A resource-based view of the firm, Strategic Management Journal. Vol. 5, No. 2, pp. 17180. 